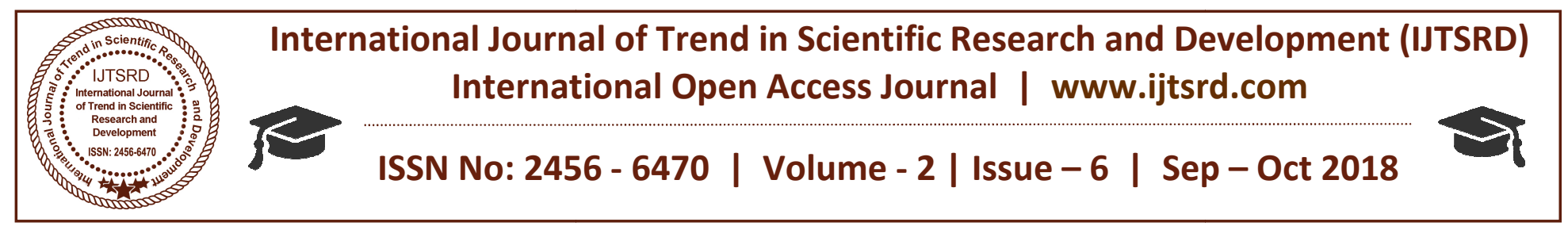

\title{
Experimental Investigation on Propertie of Bitumen Using with and with Out HDPE for Flexible Pavement
}

\author{
Singh Brijesh Kumar Shivshankar ${ }^{1}$, Pratiksha Malviya ${ }^{2}$ \\ ${ }^{1}$ M.Tech Scholar, ${ }^{2}$ Professor \\ Department of Civil Engineering, Millennium Institute of Technology, \\ Bhopal, Madhya Pradesh, India
}

\section{INTRODUCTION}

The purpose of this study is to investigate the Marshall Stability, flow and Marshall Quotient possibility of using various plastic wastes containing (Stability to flow ratio). Plastic items are used in our High Density Polyethylene as polymer additives to asphalt concrete. It was investigated that the influence of HDPE-modified binder obtained by various mixing time, mixing temperature and HDPE content on the everyday life. From greenhouse, coating and wiring, to packaging, films, covers, bags and containers. It is only reasonable to find out a considerable amount of plastic.

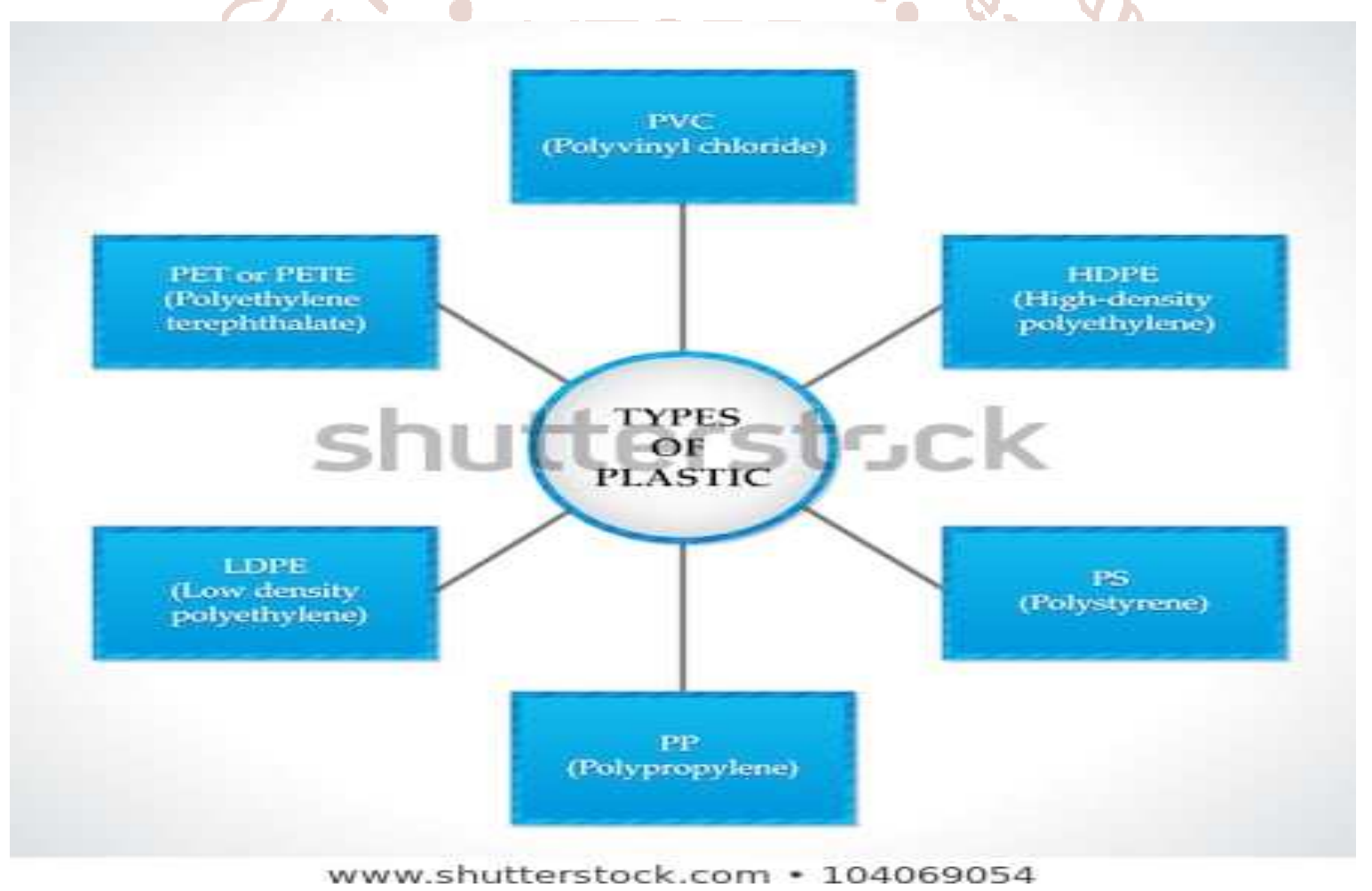

Fig. no. 1.1 Types of plastic waste

\section{Literature Survey}

This chapter presents the characteristics of SMA with fibers to justify research aim and sets the background for the proposed work.

Vasudevan et. al. (2014), introduced an examination on the arrangement of plastics squander - bitumen mix and its properties to discover the reasonableness of the mix for street development, was done. An adjusted procedure was produced and the stone total was covered with liquid plastics and the plastics squander covered total (PCA) was utilized as the crude material for adaptable development. PCA 
demonstrated better restricting property. It had less wetting property. Its voids were substantially less. The example demonstrated higher Marshall Solidness esteem. The streets laid utilizing PCA are performing admirably. A point by point contemplated is displayed.

Vasudevan et. al. (2015), additionally watched that the polymer mixed bitumen has better properties with respect to Softening point, Entrance point, Flexibility, Stripping Worth and Marshall Dependability esteem. Subsequently the mix can be utilized for laying adaptable asphalt. In this examination both dry and wet procedures were utilized to get ready changed bituminous blends. In the wet procedure, the mixing was done by straightforwardly blending the destroyed polymer with hot bitumen at $160 \mathrm{deg}$. C. In the dry procedure, a novel system was utilized to utilize higher level of waste plastics in street development and utilizing this strategy a substitute technique was utilized. In this strategy, the waste polymer was included the hot total (170deg.C). The polymer was covered over the total. Here the spreading was simple. The hot total was covered with polymer consistently. At that point the Bitumen was included. The blending of bitumen with polymer was occurring at the surface of the total. The temperature was around $155-163 \mathrm{C}$. Both the polymer and bitumen were in the fluid state.

\section{Objectives}

$>$ To study the physical properties of $60 / 70$ grade bitumen.

$>$ To study properties bitumen with HDPE and without HDPE.

\section{Results with Ordinary Bitumen}

\subsubsection{Physical Properties of Aggregate:}

Laboratory test has been performed to find the physical properties of aggregate for dense bituminous mix and the results obtained are given below in table (5.3)

Table 5.3: Physical Properties of Aggregate

\begin{tabular}{|c|c|c|c|c|c|}
\hline \multirow{2}{*}{ Property } & \multicolumn{5}{|c|}{ Aggregate } \\
\cline { 2 - 6 } & $\mathbf{2 0} \mathbf{~ m m}$ & $\mathbf{1 0} \mathbf{m m}$ & $\mathbf{6} \mathbf{~ m m}$ & Dust & Cement \\
\hline Specific Gravity & 2.72 & 2.67 & 2.63 & 2.61 & 3.07 \\
\hline Density $\left(\mathrm{g} / \mathrm{cm}^{3}\right)$ & 1.54 & 1.48 & 1.47 & 1.42 & 1.32 \\
\hline
\end{tabular}

\subsubsection{Physical properties of $60 / 70$ grade bitumen: \\ 5.3.1.4 Results of Marshal Mix Design for DBM with ordinary bitumen (60/70 grade):}

Different test were performed to find the physical properties of ordinary bitumen and the results obtained are given below in table (5.4)

Table 5.4: Physical properties of $60 / 70$ grade bitumen:

\begin{tabular}{|c|c|c|}
\hline $\begin{array}{c}\text { S. } \\
\text { No. }\end{array}$ & Properties & $\begin{array}{c}\text { Test } \\
\text { Results }\end{array}$ \\
\hline 1 & $\begin{array}{c}\text { Penetration at } \\
25^{\circ} \mathrm{C} / 100 \mathrm{gm} / 5 \mathrm{Sec}, \mathrm{mm}\end{array}$ & 65 \\
\hline 2 & Softening point, ${ }^{\circ} \mathrm{C}$ & 60 \\
\hline 3 & Ductility, cm & 98 \\
\hline 4 & Specific gravity, at $27^{\circ} \mathrm{C}$ & 1.001 \\
\hline 5 & Flash point, ${ }^{\circ} \mathrm{C}$ & 318 \\
\hline 6. & Fire point, ${ }^{\circ} \mathrm{C}$ & 340 \\
\hline
\end{tabular}

\subsubsection{Physical Properties of $60 / 70$ grade Modified Bitumen:}

Different properties of modified bitumen with the addition of HDPE percentages $(0 \%, 2 \%, 4 \%$, and $6 \%)$ were found in laboratory. The results obtained are given in the table 5.5.
Samples of ordinary bitumen were prepared with varying percentage of bitumen ( $4.5 \%$ to $6.0 \%)$ and marshal stability test were conducted on each sample. The physical properties of each sample are measured and calculated. The graphs have been plotted to find the optimum binder content which comes out to be $5.5 \%$ of bitumen. The results obtained are shown in Table 5.6.

Following graphs have been plotted to find the optimum binder content:

$>$ Binder content vs Marshal stability (fig. 5.1)

$>$ Binder content vs flow value (fig. 5.2)

$>$ Binder content vs Bulk Density (fig. 5.3)

$>$ Binder content vs Air voids (fig. 5.5)

$>$ Binder content vs Voids filled with mineral (fig. 5.5)

Binder content vs Voids filled with bitumen (fig. 5.6) 
International Journal of Trend in Scientific Research and Development (IJTSRD) ISSN: 2456-6470

Binder content vs Marshal stability

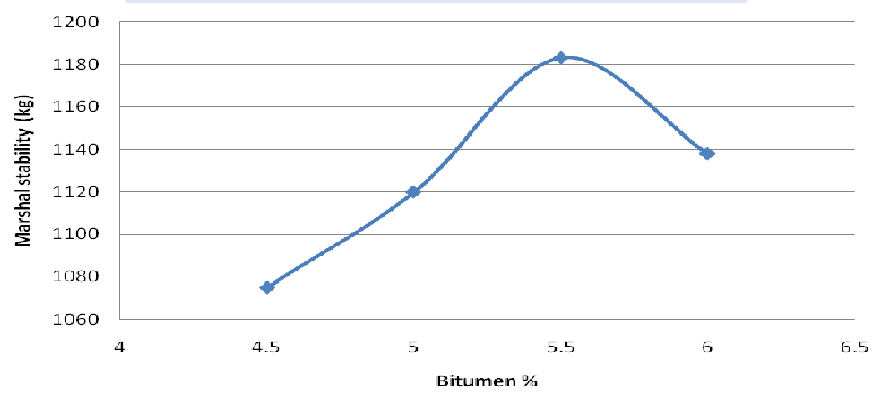

Figure 5.1: Bitumen \% Vs Marshal Stability Value Binder content vs flow value

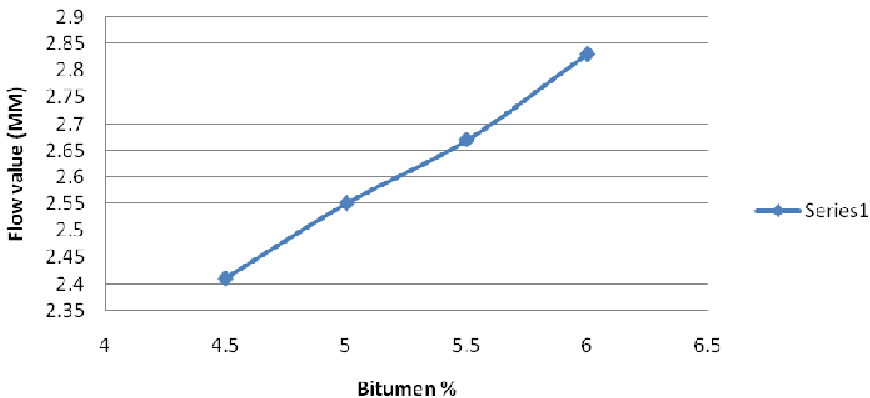

Figure 5.2: Bitumen \% Vs Flow value Binder content vs Bulk Density

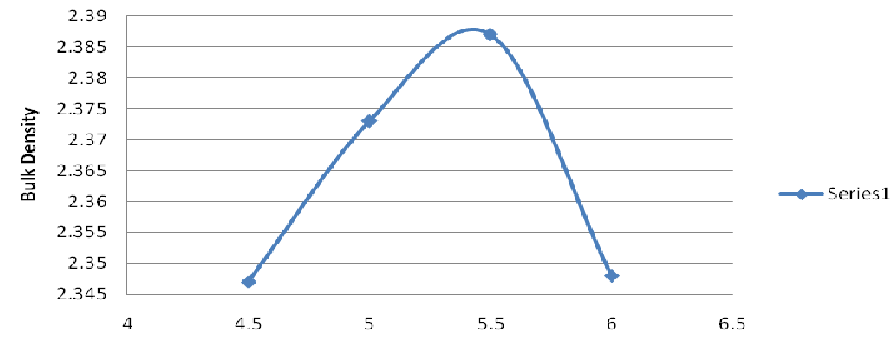

Figure 5.3: Bitumen \% Vs Bulk Density Binder content vs Air voids

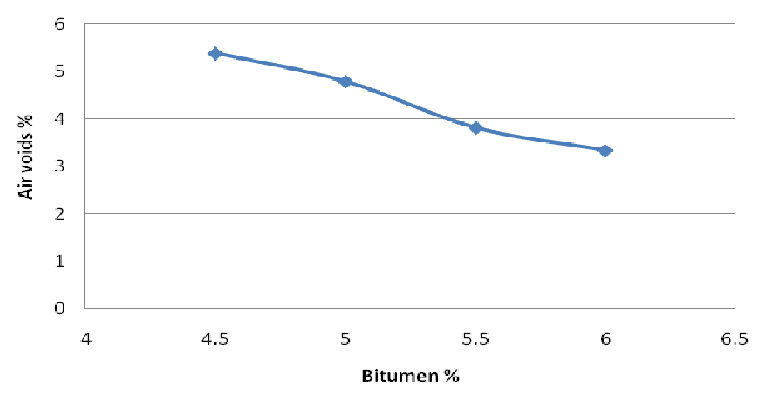

Figure 5.4: Bitumen \% Vs Air voids \%
Binder content vs VMA

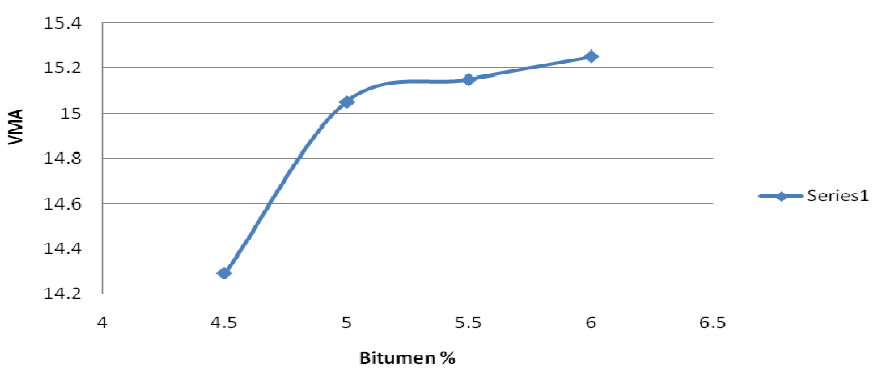

Figure 5.5: Bitumen \% Vs Voids filled with bitumen \%( VMA)

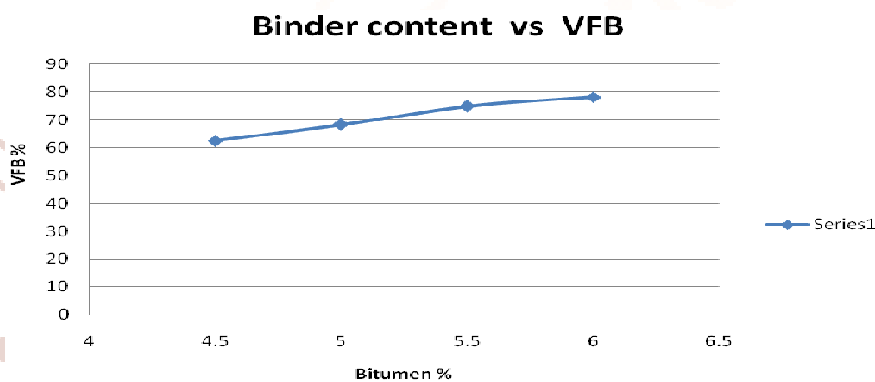

Figure 5.6: Bitumen \% Vs Voids filled with bitumen \% ( VFB)

\subsubsection{Results of DBM with HDPE:}

The results and analysis for ordinary bitumen mix shows that optimum binder content for the mix is $5.5 \%$ of the total weight of the aggregate. By using this optimum binder content i.e. $5.5 \%$ various samples of varying HDPE percentages $(2 \%, 4 \%$ and $6 \%$ ) were prepared and subsequent test have been performed to find properties of modified dense bitumen mix. The table (5.5) shows various properties of HDPE modified DBM.

The results show that increase in percentage of HDPE in mix increases marshal stability value, bulk density and voids filled with bitumen (VFB) but decreases air voids.

It has been observed that modified mix shows better properties at 4\% HDPE. Now the test were performed to find the optimum binder content with 4\% HDPE modified mix. The results obtained are given below in table (5.6).

Table 5.5: Properties of DBM with HDPE Modified bitumen when using optimum binder content $(5 \%)$

\begin{tabular}{|c|c|c|c|c|c|c|c|c|c|}
\hline \multirow[t]{2}{*}{ S.No } & \multirow[t]{2}{*}{$\begin{array}{c}\text { HDPE } \\
\%\end{array}$} & \multicolumn{2}{|c|}{$\begin{array}{l}\text { Weight of } \\
\text { sample } \\
\text { (gm) }\end{array}$} & \multirow{2}{*}{$\begin{array}{c}\text { Marshal } \\
\text { stability } \\
\text { (Kg) }\end{array}$} & \multirow[t]{2}{*}{$\begin{array}{l}\text { Flow value } \\
\text { (mm) }\end{array}$} & \multirow[t]{2}{*}{$\begin{array}{c}\text { Bullk } \\
\text { Density } \\
\text { (gm/cc) }\end{array}$} & \multirow[t]{2}{*}{$\begin{array}{c}\text { Air } \\
\text { Voids } \\
\%\end{array}$} & \multirow[t]{2}{*}{$\begin{array}{l}\text { VMA } \\
\%\end{array}$} & \multirow[t]{2}{*}{$\begin{array}{c}\text { VFB } \\
\%\end{array}$} \\
\hline & & Air & Water & & & & & & \\
\hline 1 & $2 \%$ & 1195 & 690 & 1297 & 2.45 & 2.367 & 3.97 & 13.38 & 70.34 \\
\hline 2 & $4 \%$ & 1188 & 688 & 1345 & 2.57 & 2.376 & 3.85 & 14.60 & 73.63 \\
\hline 3 & $6 \%$ & 1186 & 687 & 1445 & 2.63 & 2.378 & 3.79 & 15.26 & 75.17 \\
\hline
\end{tabular}


International Journal of Trend in Scientific Research and Development (IJTSRD) ISSN: 2456-6470

Table 5.6: Properties of DBM with 6\% HDPE modified bitumen and varying percentage of bitumen binder

\begin{tabular}{|c|c|c|c|c|c|c|c|c|c|}
\hline \multirow[t]{2}{*}{ S.No } & \multirow{2}{*}{$\begin{array}{c}\text { Bitumen } \\
\%\end{array}$} & \multicolumn{2}{|c|}{$\begin{array}{l}\text { Weight of sample } \\
\text { (gm) }\end{array}$} & \multirow{2}{*}{$\begin{array}{c}\text { Marshal } \\
\text { stability } \\
\text { (Kg) }\end{array}$} & \multirow{2}{*}{$\begin{array}{l}\text { Flow value } \\
\text { (mm) }\end{array}$} & \multirow{2}{*}{$\begin{array}{c}\text { Bulk } \\
\text { Density } \\
\text { (gm/cc) }\end{array}$} & \multirow{2}{*}{$\begin{array}{c}\text { Air } \\
\text { Voids } \\
\%\end{array}$} & \multirow{2}{*}{$\begin{array}{c}\text { VMA } \\
\%\end{array}$} & \multirow{2}{*}{$\begin{array}{c}\text { VFB } \\
\%\end{array}$} \\
\hline & & Air & Water & & & & & & \\
\hline 1 & 4 & 1193 & 692 & 1350 & 2.58 & 2.38 & 4.58 & 14.48 & 68.39 \\
\hline 2 & 4.5 & 1189 & 690 & 1390 & 2.63 & 2.39 & 4.46 & 14.97 & 70.15 \\
\hline 3 & 5 & 1188 & 693 & 1445 & 2.78 & 2.40 & 4.23 & 15.32 & 72.37 \\
\hline 4 & 5.5 & 1195 & 694 & 1410 & 2.86 & 2.385 & 4.04 & 15.46 & 75.84 \\
\hline
\end{tabular}

Following graphs have been plotted to find the optimum binder content

1. Binder content vs Marshal stability (fig. 5.7)

2. Binder content vs flow value (fig. 5.8)

3. Binder content vs Bulk Density (fig. 5.9)

4. Binder content vs Air voids (fig. 5.10)

5. Binder content vs Voids filled with bitumen (fig. 5.11)

6. Binder content vs Voids filled with bitumen (fig. 5.12)

It is observed from graphs, that maximum marshal value is obtained with $5 \%$ modified bitumen compared $5.5 \%$ ordinary bitumen in DBM.

It is therefore inferred that $6 \%$ HDPE admixture saves bitumen content, without adversely affecting Marshal Stability Value.

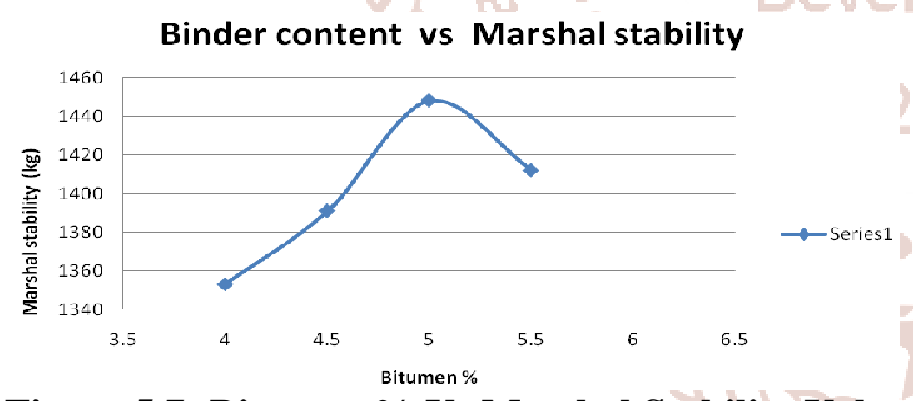

Figure 5.7: Bitumen \% Vs Marshal Stability Value

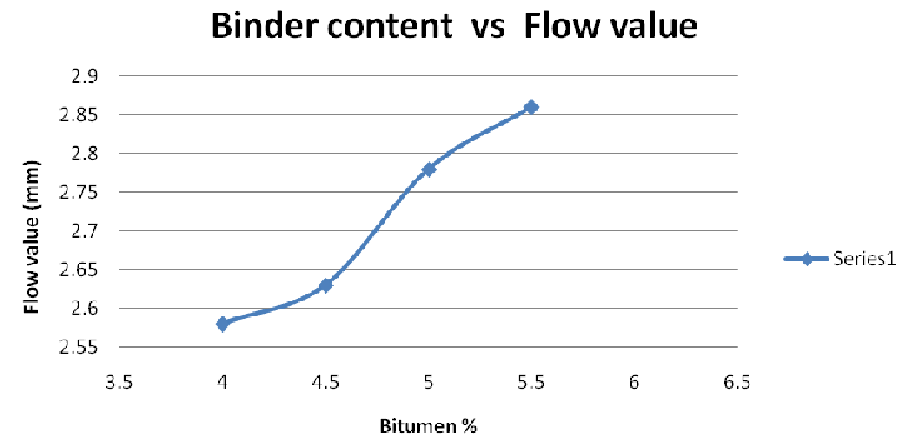

Figure 5.8: Bitumen \% Vs Flow value

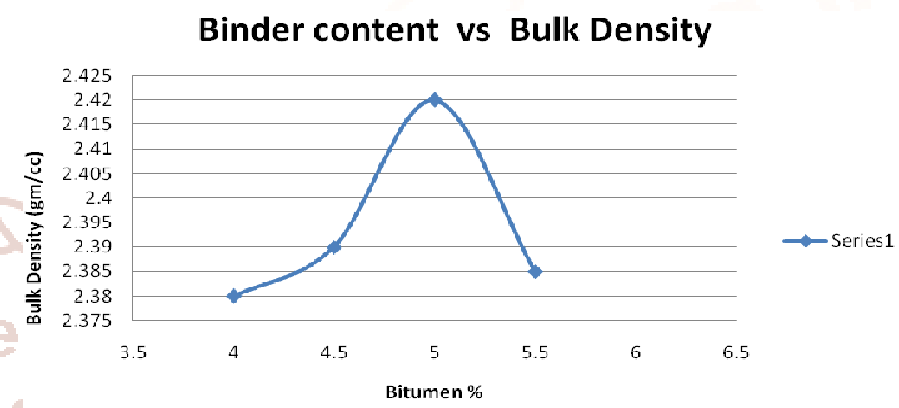

Figure5.9: Bitumen \% Vs Bulk Density

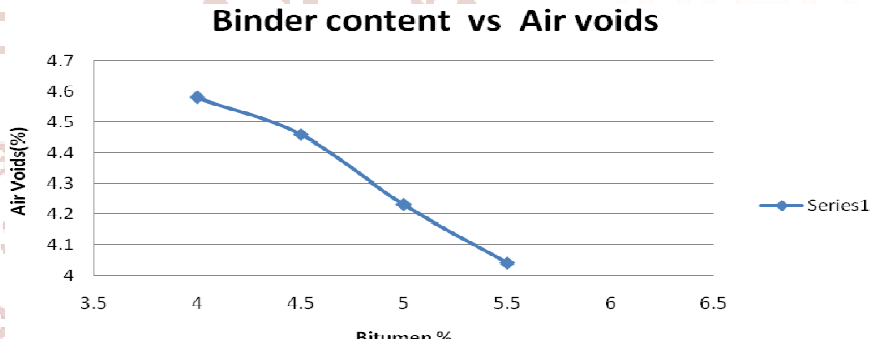

Figure 5.10: Bitumen \% Vs Air voids \%

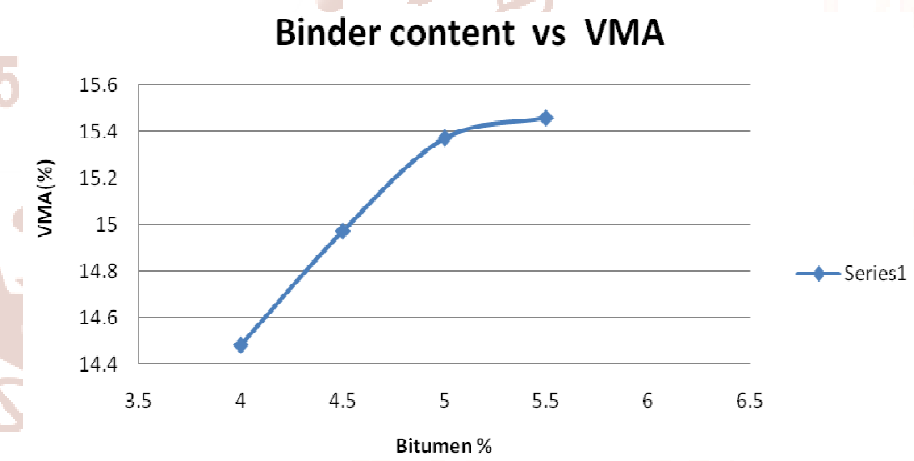

Figure 5.11: Bitumen \% Vs VMA \%

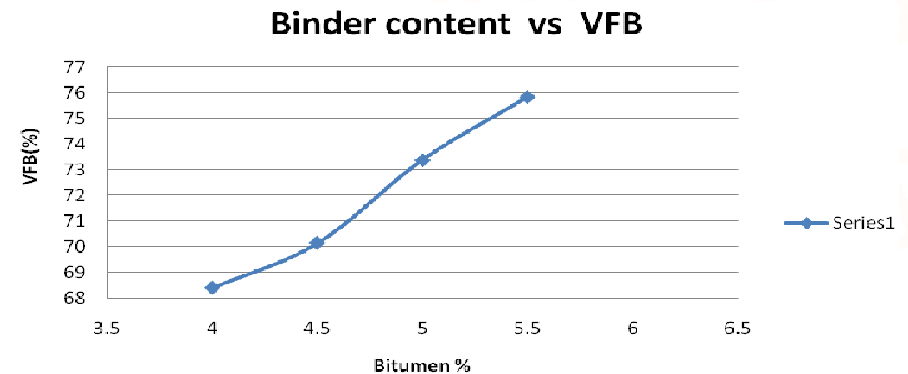

Figure 5.12: Bitumen \% Vs Voids filled with bitumen \% (VFB) 


\section{CONCLUSION}

$>$ Marshall's mix design conducted on DBM using HDPE results as per MORTH recommendations, indicate the acceptability of the HDPE in Bituminous Concrete mix, since in acceptable range.

\section{REFERENCES}

1. Aslam Shahan-ur-Rahman "Use of Waste Plastic in Construction of Flexible Pavement", New Building Materials \& Construction World 2009.

2. Chandra, R. and Rutsgi, R. (1997). "Biodegradation of Maleated Linear Low Density Polyethylene and Starch Blends." Polymer Degradation and Stabilization. 56. 185-202

3. Food Science and Technology, 14, 71-78

4. Gopalakrishnan K. S. "An Insight into Rubberized Roads, Indian Road Congress Seminar on Bituminous Roads" Design and Construction Aspects 1994. III. Effect of Amylopectin to Amylase Ratio in Starch. European Polymer Journal. 34(10): 1467- 1475.

5. IRC: SP: 53 "Guidelines on the use of polymer and rubber modified bitumen in road construction." Indian Road Congress, New Delhi 2002.
6. Justo C. E. G. , Veeraragavan A "Utilization of Waste Plastic Bags in Bituminous Mix for Improved Performance of Roads", Centre for Transportation Engineering, Bangalore University, Bangalore, India, April 2002.

7. Khan Amjad, Gangadhar, Murali Mohan, Raykar Vinay, "Effective Utilisation of Waste Plastics in Asphalting of Roads". R.V. College of Engineering, Bangalore 1999.

8. Khanna S. K., Justo C. E. G, A Text Book of Highway Engineering, Nem Chand Publication New Delhi 2001.

9. Lebbai Sheikna, S. V. Siva Prakash S. Road Construction with Plastic Wastes National Conference on Recent Trends in Engineering Sciences 2011.

10. Mali, S., \& Grossmann, M. V. E. (2003). Effects of yam starch films on storability and quality of fresh strawberries. Journal of Agricultural and Food Chemistry, 7005-7011.

11. Mali, S., L. S. Sakanaka, F. Yamashita and M. V. E. Grossman. 2005. "Water Sorption and Mechanical Properties of Cassava Starch Films and Their Relation to Plastisizing Effect. Carbohydrate Polymer". 60(3): 283-289. 